\title{
Biochemistry of cheese ripening
}

\section{Pagthinathan and M.S.M. Nafees}

Department of Animal Science, Faculty of Agriculture, Eastern University, Chenkalady, Sri Lanka pagthymp@gmail.com

\begin{abstract}
Cheese ripening basically includes the breakdown of proteins, lipids and carbohydrates which releases flavour compounds and modifies cheese texture. Principal ripening agents are milk enzymes (plasmin and lipoprotein lipase), milk coagulant, starter lactic culture, secondary culture and ripening agents. The ripening process of cheese is very complex and involves microbiological and biochemical changes to the curd resulting in the flavour and texture characteristics of the particular variety. Microbiological changes during ripening include the death and lysis of starter cells, nonstarter lactic acid bacteria, and secondary microflora in many varieties of cheese. Moulds in mould-ripened varieties and a complex Gram-positive bacterial flora in smear cheeses are of great importance to the flavour and texture of cheese. Cheese texture softens during ripening as a consequence of proteolysis of the casein micelle and changes to the water-binding ability of the curd and in $\mathrm{pH}$. The biochemical changes occurring during ripening may be grouped into primary events that include the metabolism of residual lactose, lactate and citrate (glycolysis), lipolysis and proteolysis. Following the primary events, secondary biochemical events occur which are responsible for the development of many volatile flavour compounds of ripened cheese varieties.
\end{abstract}

Keywords: Amino acid catabolism, cheese flavour, cheese ripening, metabolism of fatty acids, metabolism of lactate, proteolysis

\section{Introduction}

The ripening of cheese is a very complex process which involves microbiological and biochemical changes leading to the development of flavor and texture characteristics of cheese. Microbiological ripening includes the death and auto-lysis of starter cells, the growth of an adventitious flora (nonstarter lactic acid bacteria) and secondary microflora (McSweeney, 2004b). The biochemical reactions occurring during ripening are classified into primary and secondary biochemical events. Primary events are the metabolism of residual lactose, lactate and citrate (glycolysis), lipolysis and proteolysis. Secondary biochemical reactions are followed by primary events, which are very important for the generation of many volatile flavor compounds in cheese (Fox et al., 2000; McSweeney, 2004b). Biochemical processes of cheese ripening have previously been elucidated by several researchers (McSweeney and Sousa, 2000; Sousa et al., 2001; Smit et al., 2002; Katechaki et al., 2009).

Flavour, texture and aroma are very important features of cheese (Awad, 2006). Consumers make their choice of cheese primarily based on flavour and texture characteristics (Awad, 2006). Flavour development in cheese is of major economic interest since final flavour of cheese determines consumer choice. Development of flavour in cheese is a complex series of microbiological, biochemical and chemical processes that occur during ripening in cheese (Yvon and Rijnen 2001; Walstra et al., 2006; Hannon et al., 2007). Flavour compounds are formed by various processes acting in a concerted and/or sequential manner including conversion of lactose and citrate, fatty acids, and peptides and amino acids (McSweeney, 2004a; McSweeney, 2004b). Lactic fermentation is responsible for the initial stage of flavour compounds formed by the starter bacteria, and plays an important role in cheese ripening (Fox et al., 2000. The salt content is also important to the flavour and quality of cheese (Pastorino et al., 2003; Awad, 2007). However, many studies have found that most of the flavour components are developed 
during cheese ripening (Fox et al., 2000; McSweeney, 2004a; McSweeney, 2004b; Walstra et al., 2006).

\section{Metabolism of residual lactose and citrate}

The primary glycolytic process is the metabolism of lactose to lactate by the starter culture during early stages of ripening. If glycolysis is incomplete by the starter culture, the non-starter lactobacillis may take part in the process of glycolysis (Fox et $a l ., 2000)$. It has also been reported that the rate and extent of lactose metabolism influence the initial texture of the curd (McSweeney, 2004a). A large amount $(96 \%)$ of lactose in milk is lost in the whey as lactose or lactate (Fox et al., 2000). However, considerable amount of lactose remains in fresh curd, which can significantly affect cheese quality (McSweeney, 2004b). In the early part of ripening, residual lactose is quickly metabolised to form L-Lactate. The rate and extent of reaction are dependent on the temperature and salt-inmoisture (S/M) levels of the curd. When S/M levels increase, starter activity is slowly stopped at the end of manufacture (Fox et al., 2000; McSweeney, 2004a; Parente and Cogan, 2004).

The rate of lactic acid formation during cheese ripening has a direct effect on the taste of cheese, especially in young cheese (Fox et al., 2000). DLactate could be produced directly from residual lactose by starter lactobacilli or by racemisation of L-lactate by non-starter lactic acid bacteria (NSLAB - eg: pediococci), during ripening of cheese (Fox et al., 2000; McSweeney, 2004a). The lactate racemisation of lactate generally involves oxidation of L-lactate to form pyruvate by L-lactate dehydrogenase, which is then converted to D-lactate by D-lactate dehydrogenase. DL-lactate is less soluble than $\mathrm{L}-$ lactate, resulting in the formation of Ca-DL -lactate crystals which appear as white specks on the surface of the mature cheese (Dybing et al., 1998; McSweeney, 2004b). While the crystals are harmless, they may reduce consumer's interest (McSweeney, 2004b). Lactate can also be metabolised by lactic acid bacteria (LAB) to produce flavour compounds including acetate, ethanol, formate and $\mathrm{CO}_{2}$. However, the extent of this process depends on the population of NSLAB and the presence of $\mathrm{O}_{2}$ (McSweeney, 2004b). Citrates have a relatively lower concentration in milk, most of which is in the soluble phase and is drained through the whey. According to McSweeney and Fox (2004), 0.2-0.5\% of citrate is present in Cheddar cheese. In the presence of mesophilic lactobacilli starter cultures, citrate can be metabolised to produce certain flavour compounds, including diacetyl, acetoin, acetate and 2,3- butanediol, which contribute to the flavour of cheese (Cogan and Hill, 1993; de Figueroa et al., 2000,2001; McSweeney, 2004b).

\section{Degradation of lipids}

Cheese lipids may involve hydrolytic or oxidative degradation by the action of indigenous, endogenous and/or exogenous lipases, which result in the liberation of free fatty acids in cheese during ripening, as shown in Figure 1. (Bosset et al., 1993; Fox et al., 1995; McSweeney, 2004a; Walstra et al., 2006). The milk fat is rich in short-chain fatty acids, which are important precursors for the production of volatile flavour compounds that considerably contribute to the development of flavour in many cheese varieties (Collins et al., 2003; Alewijn et al., 2005). Lipolysis occurs in all varieties of cheese, but excessive lipolysis can result in rancidity (Collins et al., 2003; McSweeney, 2004b). Further, it has also been reported that free fatty acids were counterbalanced with other flavour compounds to develop an appreciated aroma (Bosset and Gauch, 1993; Fox et al., 1995). Lipases generally originate from the milk, rennet preparation, starter, adjunct starter, nonstarter, and secondary microorganisms and exogenous lipase (Deeth, and Fitz-Gerald, 1995; Fox and Wallace, 1997; McSweeney and Sousa, 2000).

Milk contains an indigenous lipase, which is called as lipoprotein lipase (LPL) (Fox and Stepaniak, 1993; Fox et al., 1993). The fat does not hydrolyse under normal circumstance because substrate (fat) and enzyme (LPL) are compartmentalised by the milk fat globule membrane (MFGM) and most of LPL is associated with the casein micelles (Collins et al., 2003; McSweeney, 2004b). The rupture of MFGM due to homogenisation, agitation, foaming and freezing, could cause significant lipolysis, resulting in off-flavors in cheese (Fox et al., 2000; Collins et al., 2003; McSweeney, 2004b). 


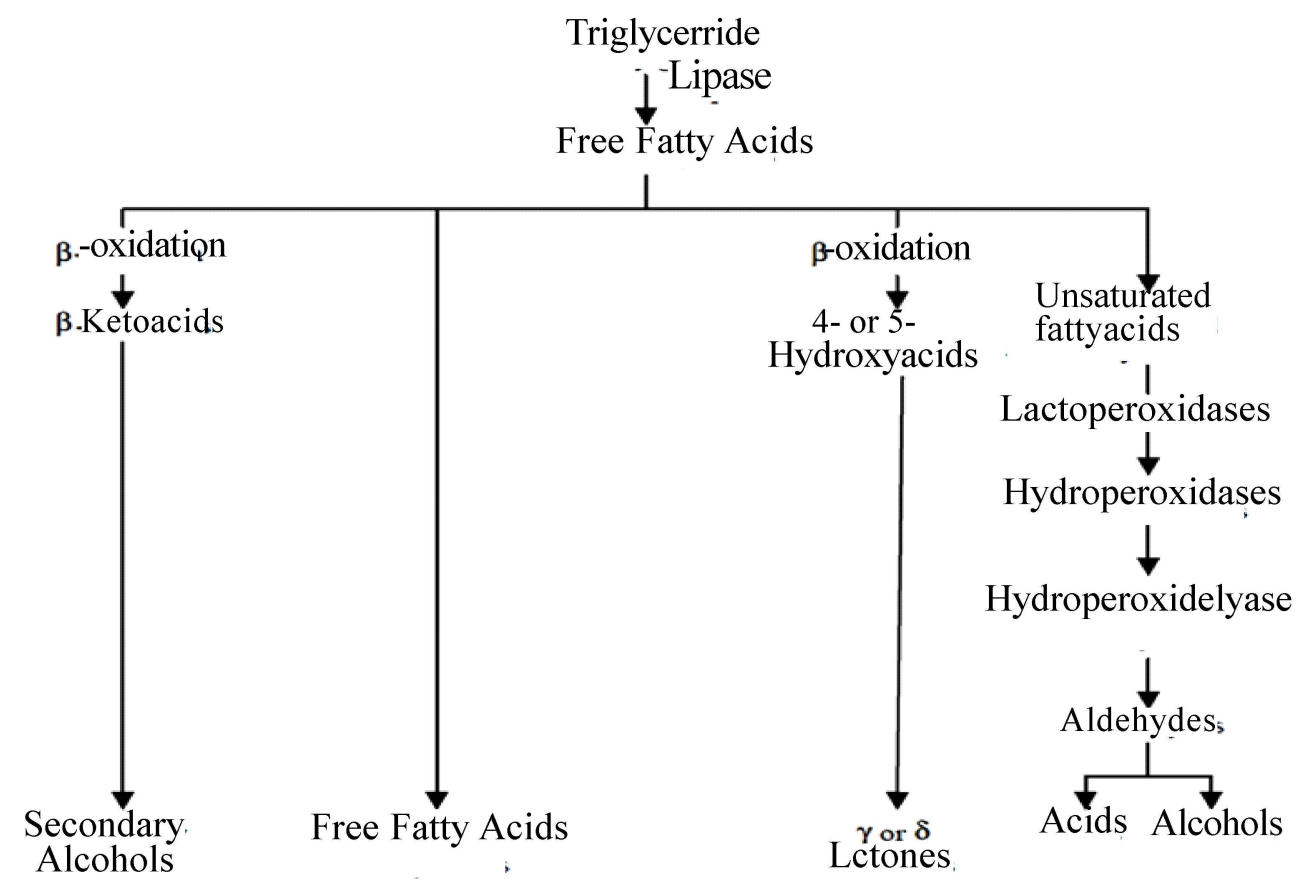

Figure 1. Catabolism of Free Fatty Acids (Source : Collins et al., 2003)

LPL is preferable for hydrolysis of triglycerides containing short and medium-chain fatty acids (Deckelbaum et al., 1990; Fox et al., 2000), and acts preferentially $\mathrm{C}_{4: 0}$ and $\mathrm{C}_{6: 0}$ located at the $s n-1$ and $s n-3$ positions of triglycerides (Olivecrona $e t$ al., 1992; Collins et al., 2003). LPL is probably heat liable and is largely inactivated by HTST pasteurization, although $78^{\circ} \mathrm{C}$ for $10 \mathrm{~s}$ is required for complete inactivation of this enzyme (Fox et al., 2000; McSweeney, 2004b). Collins et al. (2003) reported that the LPL activity is most significant in raw milk cheeses than in cheese made from pasteurised milk. Moreover, rennet paste, used as a coagulant in certain Italian cheese varieties, contains a potent lipase and pregastric esterase, which are responsible for lipolysis in those type cheeses (McSweeney, 2004b). The Lactic acid bacteria are also capable to lipolysis of fat, and their enzymes have been shown to contribute to significant level of lipolysis characteristics in Cheddar cheese (Collins et al., 2003; McSweeney, 2004a, 2004b).

\section{Catabolism of free fatty acid}

Fatty acids have a direct impact on the flavour of many cheese varieties, e.g. $\mathrm{C}_{4}-\mathrm{C}_{10}$ acids are particularly strongly flavoured (Collins et al., 2003). Free fatty acids, especially short-medium chain fatty acids, are important precursors for the production of volatile flavour compounds through a series of metabolic processes during ripening of cheese (McSweeney and Sousa, 2000; Walstra et al., 2006). The enzymatic system permits the $\beta$-oxidation of fatty acid to a $\beta$-keto acid, which is rapidly de-carboxilated to give methyl ketone (Figure 2) (McSweeney, 2004a; Dimitrellou et al., 2009). Collins et al. (2003) reported that the methyl ketones are the most important flavour compound, depending on types of cheese and concentration of methyl ketone. The formation of methyl ketones is influenced by several factors including temperature, $\mathrm{pH}$ of cheese ( $\mathrm{pH}$ 5-7), concentration of precursor FFA and physiological state of the mould. Methyl ketones may also be reduced to form the corresponding secondary alcohol by the action of $P$. roquefort $i$ enzymes (Collins et al., 2003; Walstra et al., 2006).

The lactones in cheese are $\gamma$-decalactone and $\delta$-decalactone, which contribute to the flavour of a number of cheese varieties (McSweeney, 2004a). These compounds are formed from hydroxyacids following intramolecular esterification (Collins et al., 2003). Hydroxyacid are produced from oxidation of fatty acids by the action of lipoxygenases and other enzymes present in cow milk (Collins et 


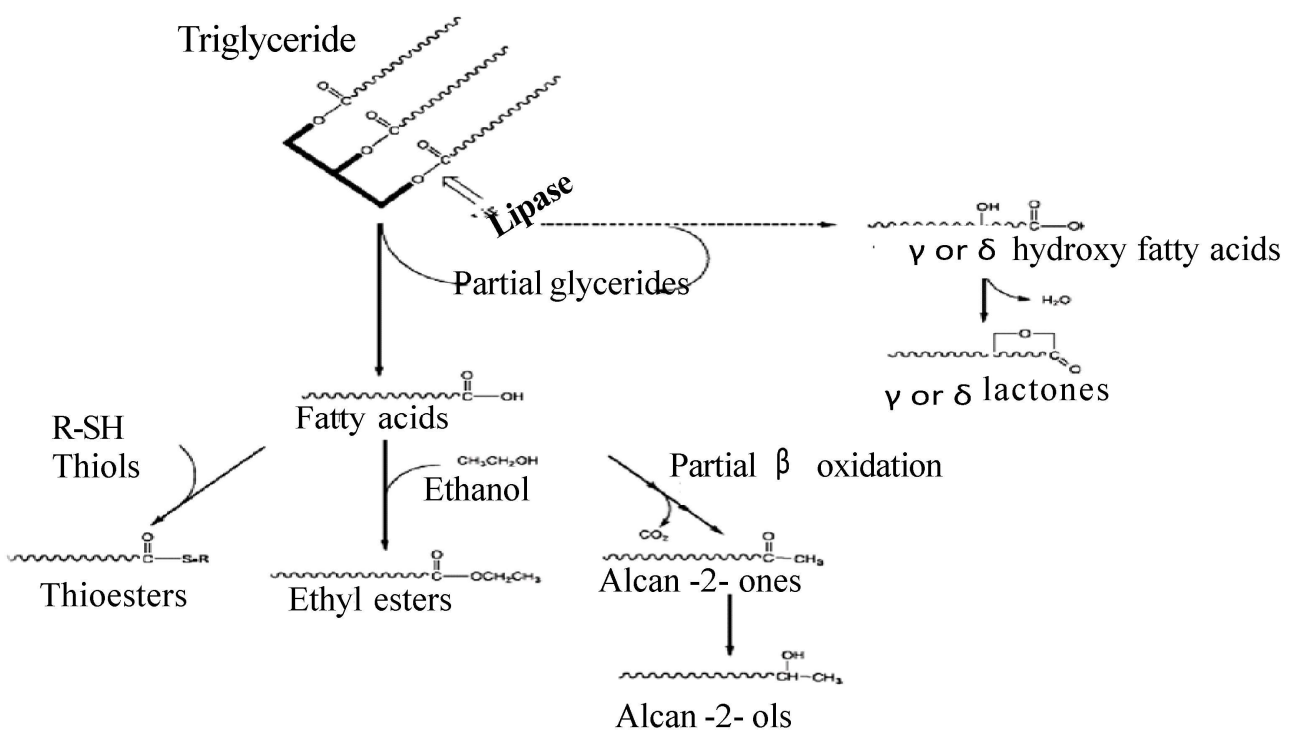

Figure 2 : Fatty acid metabolism during ripening (Source : McSweeney, 2004a)

al.,2003; McSweeney, 2004a). Dodecalactones may be formed by $P$. roqueforti from long-chain of unsaturated fatty acids (Chalier and Crouzet, 1992). Collins et al. (2003) reported that disproportionate amounts of high molecular mass lactones caused rancidity in Cheddar cheese. In addition, esters are formed by reaction of fatty acids with an alcohol, and the ethyl esters are most common in cheese (McSweeney, 2004a). Thioester compounds are also produced when fatty acid reacts with catabolic products of sulphur-containing amino acids (Molimard and Spinnler, 1996; Collins et al.,2003).

\section{Degradation of protein}

Proteolysis is the most complex, and important biochemical event in cheese ripening (Yvon and Rijnen, 2001; Dimitrellou et al., 2010). Proteolysis plays a vital role in the development of texture as well as flavour (Sousa et al., 2001). Proteolysis is contributing to the softening of cheese texture during ripening due to the hydrolyzing para-casein matrix, decreasing the water activity $(a \mathrm{w})$ through water binding by liberated carboxylic acids, forming the amino groups by hydrolysis (Sousa et al., 2001; McSweeney, 2004b). Proteolysis may have a direct impact on cheese flavour through theformation of short peptides and amino acids, which may cause an off-flavour to cheese (McSweeney, 2004a). However, McSweeney and Sousa (2000) and Yvon and Rijnen (2001) indicated that the role of proteolysis in cheese flavour is a production of peptides and amino acids which act as precursors for catabolic reactions, resulting in production of many important volatile flavour compounds. Sousa $e t$ al. (2001) reported that in most cheeses, the initial proteolysis of caseins occurred mainly by the coagulant, and to some extent, by plasmin and somatic cell proteinases (cathepsin D), and release the large and intermediate-sized peptides which are subsequently hydrolysed by the coagulant and microbial enzymes. Microbial proteinases generally produce the small peptides and amino acids in cheese probably, by hydrolyzing the large peptides produced from $\alpha_{\mathrm{s} 1-}$ casein and $\beta$-casein by action of chymosin and plasmin respectively, whereas free amino acids are produced from short peptides by microbial peptidase (Sousa et al., 2001; McSweeney, 2004a,b).

During cheese ripening, proteinases and peptidases originate from the coagulant, milk, starter LAB, NSLAB, secondary starters and exogenous proteinases or peptidases added in curd to accelerate the ripening (Fox et al., 
2000). Plant proteases have also been investigated as source of milk coagulants for cheese production. So far, only a few plant aspartic proteinases have been isolated and partially characterised (Tavaria et al., 1997; Bruno et al., 2010). Most plant coagulants were reported to have low ratio of milk-clotting to proteolytic activity, which results in bitter peptides in ripened cheese, and low yield of cheese production (Sousa et al., 2001).

The major source of milk coagulant is calf rennet, which contains two types of proteolytic enzymes naturally, chymosin (EC 3.4.23.4) (88-94\%) and bovine pepsin (EC 3.4.23.1) (6-12\%) (Sousa, et al., 2001). The principal and essential role of the coagulant in cheese making is to coagulate milk. Some coagulant activity is retained in the curd to contribute to proteolytic activity during ripening in many varieties of cheeses (Sousa et al., 2001). Other enzymes found to be a source of coagulants for cheese production include pepsin (Rhizomucor) and proteinases (Cryphonectria parasitcia, Cynara cardunculus) (Fox et al., 2000; McSweeney, 2004b; Nourani et al., 2009).

Milk contains several indigenous proteinases. Plasmin is a principal indigenous proteinase, and is a trypsin-like serine proteinase. It acts optimally at $\mathrm{pH} 7.5$ and $37^{\circ} \mathrm{C}$ and heat stable up to $55^{\circ} \mathrm{C}$. The plasmin activity is more significant in cheese types which are cooked to high temperature because high temperatures probably inactivate the plasmin inhibitors (McSweeney, 2004a). The plasmin is active on caseins in the order $\beta$-casein $\mathrm{H}^{\prime \prime} \alpha \mathrm{s} 2-$ casein $>\alpha \mathrm{s} 1$-casein. $\kappa$-Casein seems to be quite resistant to the action of plasmin (Fox et al., 2000). In addition, milk contains many other proteolytic enzymes such as cathepsin D and cathepsin B, which have been confirmed for the milk coagulation activity (Hurley et al., 2000; Magboul et al., 2001; McSweeney, 2004b).

Lactic acid bacteria (LAB) are proteolytic, and possess a proteinase and a wide range of peptidase, which are important for the final stages of proteolysis in cheese ripening, ultimately producing small peptides and amino acids in cheese (Fox et al., 2000). The proteolytic system of Lactococcus is basically composed of a cell envelope-associated proteinase (CEP) or PrtP, and intracellular proteinases especially peptidases and tripeptidases (Christensen et al., 1999; McSweeney, 2004b). It has been reported that proteinase (PrtP) contributes to the formation of small peptides in cheese by hydrolysing larger peptides produced from $\alpha_{\mathrm{s} 1}-$ casein and $\beta$ - casein by chymosin and plasmin, respectively, whereas intracellular peptidases such aminopeptidases, dipeptidases and tripeptidases liberate the free amino acids from small peptides ( Fox et al., 2000; McSweeney, $2004 \mathrm{~b}$ ). In addition, non - starter LAB (NSLAB) is involved in the ripening of nearly all types of cheese, especially Cheddar cheese (Fox et al., 2000). The activity of the NSLAB appears to supplemets the proteolytic action of the starter (McSweeney, 2004a). However, NSLAB seems to be not only contributing proteolysis in Cheddar cheese, but also to the release of free amino acids (Fox and McSweeney, 1998).

\section{Catabolism of free amino acid}

The catabolism of the free amino acids during ripening has produced many flavor compounds (McSweeney and Sousa, 2000; Yvon and Rijnen, 2001). Products of amino acid catabolism contribute as precursors to the development of volatile flavour compounds in cheese (Katechaki et al., 2009).

Amino acids are grouped into branched-chain amino acids, aromatic amino acids and methionine. They act as a substrate for aminotransferase (lyase), decarboxylation, deamination, dehydrogenation, oxidation and reduction reactions to produce a variety of flavor compounds during cheese ripening (Yvon and Rijnen, 2001; Marilley and Casey, 2004; McSweeney, 2004a,b; Dimitrellou et al., 2010).

\section{Catabolism of branched-chain amino acids}

Catabolism of branched-chain amino acids such as leucine, isoleucine and valine are initiated by the action of aminotransferase producing corresponding $\alpha$-keto acids ( $\alpha$-ketoisocaproate, $\alpha$-keto- $\beta$-methyl valerate and $\alpha$-ketoisovalerate, respectively) (Yvon and Rijnen 2001; Marilley and Casey, 2004). Further, the $\alpha$-keto acids are 
degraded to other compounds by enzymatic or non enzymatic reactions (McSweeney, 2004b) and may be involved in a series of biochemical reactions such as oxidative decarboxylation, decarboxylation and reduction as illustrated in Figure 3, releasing volatile flavour compounds including phenylacetic acid, phenethanol, p-cresol, methane thiol, dimethyl disulphide, 3-methyl butyrate, 3-methyl butanal, 3-methyl butanol, 3- methyl-2-butanone, 2-methyl propionate, 2methyl-1-propanal, 2-methyl butyrate, and 2methyl butanal (Rychlik and Bosset, 2001; Yvon and Rijnen 2001; Marilley and Casey, 2004; McSweeney, 2004). Curtin and McSweeney (2004) reported that aminotransferase is a ratelimiting step for the production of flavour compounds in cheese.

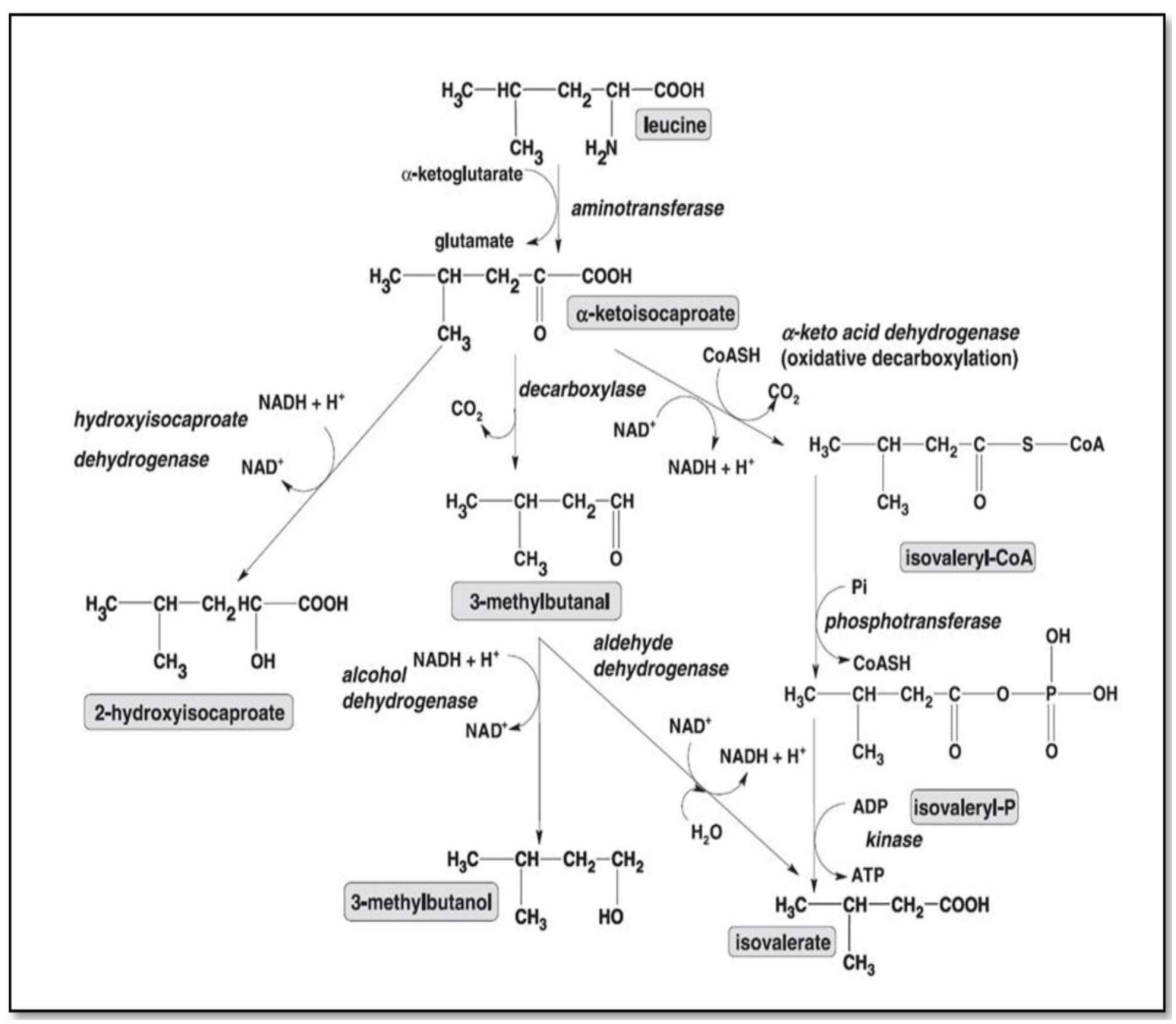

Figure 3 Catabolism of Branched- Chain Amino Acids

(Source: Marilley and Casey, 2004)

\section{Catabolism of aromatic amino acids}

The first step of the catabolism of aromatic amino acids is by transamination (Figure 4), which produces $\alpha$-keto acids indole pyruvate, phenyl pyruvate and p-hydroxy-phenyl pyruvate from tryptophan, phenylalanine and tyrosine, respectively (Yvon and Rijnen 2001; Marilley and Casey, 2004). The $\alpha$-keto acids are further catabolised in a series of metabolic pathways to produce flavor compounds in cheese ripening (McSweeney, 2004b), which includes benzaldehyde, phenyl acetaldehyde, phenyl ethanol, phenyl acetate, phenyl propanoate, indole, skatole and p-Cresol (Moio et al., 2000; Curioni. and Bosset, 2002; McSweeney, 2004b). 


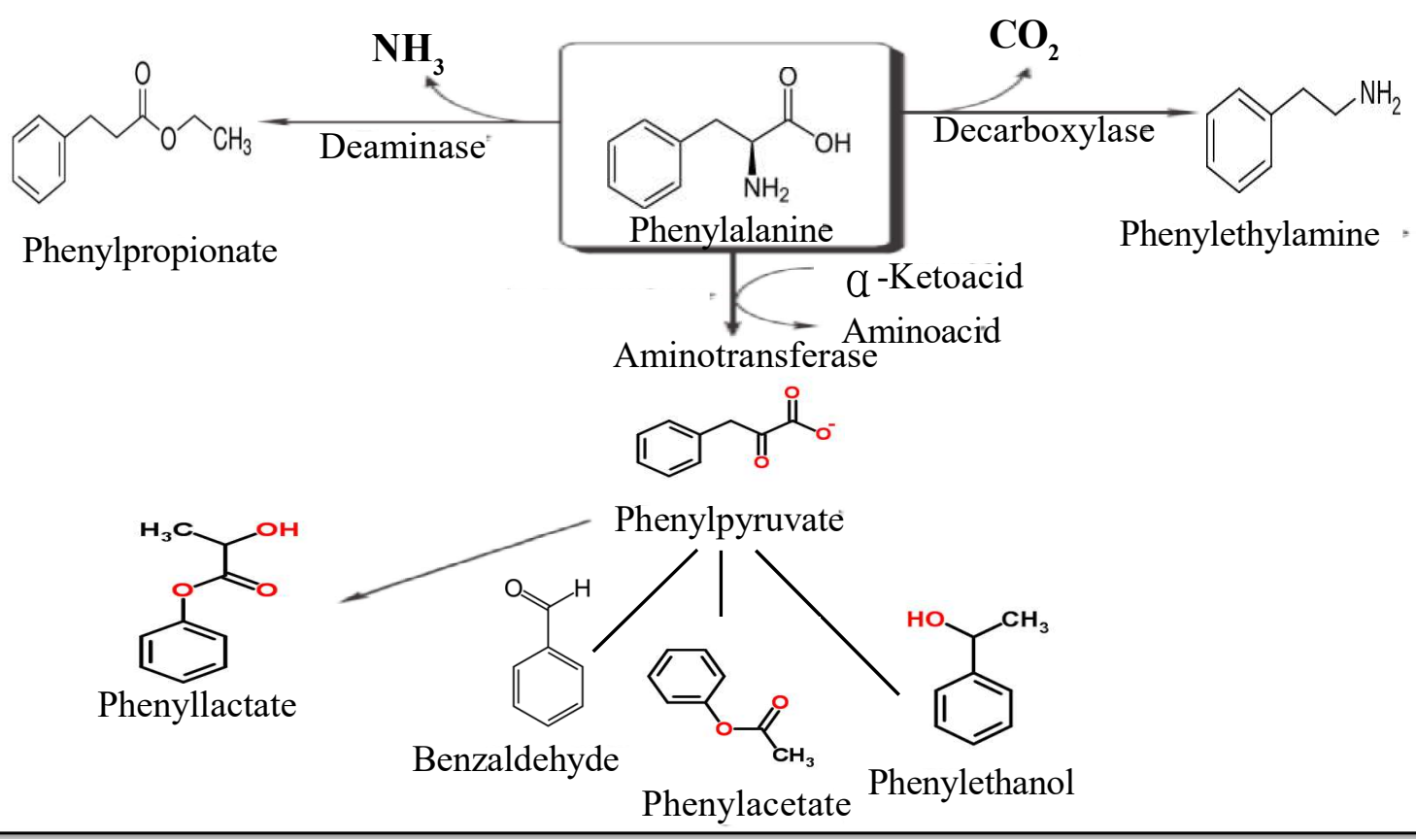

Figure 4. Catabolic pathways of phenylalanine

(Source: McSweeney, 2004b)

\section{Catabolism of methionine}

Sulphur-containing volatile compounds are important flavours in many cheese varieties, especially in Cheddar cheese and are major contributors to aroma development in cheese
(McSweeney and Sousa, 2000). The degradation of sulphur-containing amino acid (methionine) is also initiated by a transamination producing 4-methylthio- 2-ketobutyric acid (Figure 5) (Marilley and Casey, 2004). Demethiolation or/ and decarboxylation of 4-

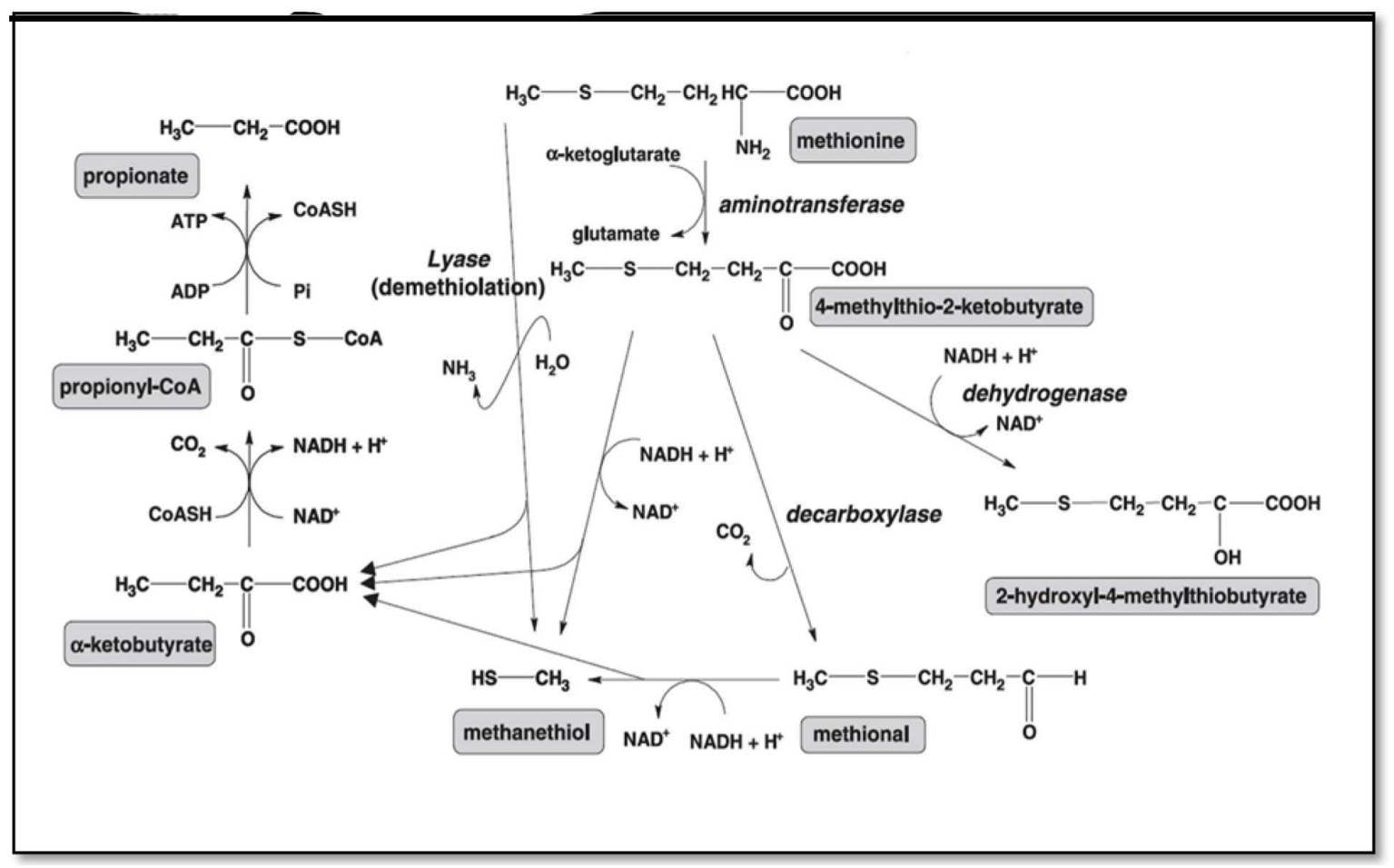

Figure 5. Catabolism of methionine and generation of volatile sulphur compound

(Source: Marilley and Casey, 2004) 
methylthio-2-ketobutyric acid liberate the sulphurcontaining flavour compounds including, dimethyl disulphide, dimethyl trisulphide, S-methyl thioacetate, boiled potato-like (methional) and cooked cabbage like methanethiol (McSweeney and Sousa, 2000; Yvon and Rijnen, 2001; Thierry and Maillard, 2002; Marilley and Casey, 2004). In addition to ammonia produced by deamination, it contributes to flavour in certain varieties of smear cheese. It may also contribute to elevation of cheese $\mathrm{pH}$ during ripening. Decarboxylation of amino acids produce amine, which has strong and unpleasant aroma, and adversely affects the cheese quality. The rate of amine production usually depends on the concentration of precursor amino acids, cheese micro flora (non-starter lactobacilli and enterococci), ripening temperature, $\mathrm{pH}$ and salt concentration (Curtin and McSweeney, 2004; McSweeney, 2004a; McSweeney, 2004b).

\section{Microbial ripening}

Cheese contains a diversity of microorganisms and enzymes which could cause biological, biochemical and chemical changes in all varieties of cheeses. Generally in all cheeses, the enzymes originating from the milk, coagulant and starter are not sufficient to make a ripening (Fox et al., 2000; Shetty et al., 2006). The action of these enzymes combined with enzymes from the secondary microflora induces changes to the flavour, aroma and texture in cheese during ripening. The rate and extent of microbial ripening is directly dependent on the percentage salt-inmoisture in the in cheese (Fox et al., 2000). Microbial ripening is mainly dependent on $\mathrm{pH}$, ripening temperature, water activity, and concentration of salt, oxidation reduction potential, $\mathrm{NO}_{3}$, and other compounds (bacteriocins). However, cheese ripening involves the combination of microbial and biochemical changes in cheese (Fox et al., 2000; Curtin and McSweeney, 2004).

\section{Summary}

Cheese ripening involves a very complex series of biochemical reactions by living organisms or by enzymes from several sources. The primary events are glycolysis, lipolysis and proteolysis. The fermentation of lactose mainly to lactic acid is caused by starter microorganisms. Lipolysis is quite limited in most cheese. However the proteolysis is the most complex process, which is not possible to characterize in detail. The primary reactions such as increase in $\mathrm{pH}$ and hydrolysis of protein matrix are primarily responsible for changes in cheese texture, but they are a minor contribution to cheese flavor. The catabolism of lactic acid has minor influence on the flavor of most cheeses. The catabolism of fatty acid to methyl ketones via $\beta$-oxidation and decarboxilation are a major contribution to flavor characters of some cheese (eg. blue molt ripened cheese). While the catabolism of amino acid is a major contribution to the flavor of many cheese varieties. Lactic acid metabolism and the ammonia produced in many of the reactions are contributing to the $\mathrm{pH}$ of cheese during ripening, and this change in the $\mathrm{pH}$ affects the texture of the cheese, salability and activity of the enzyme. Since the biochemistry of cheese ripening is responsible for the development of flavor, texture and appearance, these biochemical reactions are a prerequisite for controlling and modifying cheese ripening. In general, this biochemical reactions, particularly secondary reaction of amino acid catabolism remain as challenges for future researchers in this area.

\section{References}

Alewijn, M., E.L. Sliwinski and J.T.M. Wouters (2005). Production of fat-derived (flavour) compounds during the ripening of Gouda cheese. International Dairy Journal 15: 733-740.

Awad, S. (2006). Texture and flavour development in Ras cheese made from raw and pasteurized milk. Food chemistry 97: 394-400.

Awad, S. (2007). Effect of sodium chloride and $\mathrm{pH}$ on the rennet coagulation and gel firmness. LWT 40: 220-224. 
Bosset, J.O. and R. Gauch (1993). Comparison of the volatile flavour compounds of six European 'AOC' cheeses by using a new dynamic headspace GCMS method. International Dairy Journal 3: 359377.

Bruno, M. A., M.C. Lazza., M.E. Errasti., L.M.I. Lò pez., N.O. Caffini and M.F. Pardo (2010). Milk clotting and proteolytic activity of an enzyme preparation from Bromelia hieronymi fruits. LWT - Food Science and Technology 43 (4): 695-701.

Chalier, P. and J. Crouzet (1992). Production of lactones by Penicillium roqueforti. Biotechnology Letters 14:275-280.

Christensen, J.E., E.G. Dudley., J.A. Pederson and J.L. Steele (1999). Peptidases and amino acid catabolism in lactic acid bacteria. Antonie van Leeuwenhoek, 76: 217-246.

Cogan, T. M. and C. Hill (1993). Cheese starter cultures. In Cheese: Chemistry, Physics and Microbiology, Vol 1: General Aspects, 2nd edn, pp 193-256. Fox P F, ed.London: Chapman and Hall.

Collins, Y. F., P.L.H. McSweeney and M.G. Wilkinson (2003). Lipolysis and free fatty acid catabolism in cheese: a review of current knowledge. International Dairy Journal 13: 841-866

Curioni, P.M.G. and J.O. Bosset (2002). Key odorants in various cheese types as determined by gas chromatographyolfactometry. International Dairy Journal 12: 959-984.

Curtin, A. C. and P.L.H. McSweeney (2004). Catabolism of amino acids in cheese during ripening. In Cheese: Chemistry, Physics and Microbiology, Vol 1: General Aspects, 3rd edn, pp 435-454. Fox, P. F., McSweeney, P. L. H, Cogan, T. M. and Guinee, T. P., eds. London: Elsevier.
Deckelbaum, R. J., J.A. Hamilton., A. Moser., G. Bengtsson-Olivecrona., E.Butbul., Y.A. Carpentier., A. Gutman and T. Olivecrona (1990). Medium-chain versus long chain triacylglycerol emulsion hydrolysis by lipoprotein lipase and hepaticlipase: Implications for the mechanisms of lipase action. Biochemistry 29: 1136-1142.

Deeth, H. C. and Fitz-Gerald, C. H. (1995). Lipolyticenzymes and hydrolytic rancidity in milk and milk products. In P. F. Fox (Ed.), Advanced dairy chemistry-2-Lipids (pp. 247-308). London: Chapman \& Hall.

de Figueroa, R., F. Alvarez., A. Pesce de Ruiz Holgado., G. Oliver and F. Sesma (2000). Citrate utilization by homo- and heterofermentative lactobacilli. Microbiologyn Research 154: 313320.

de Figueroa, R.M., G. Oliver and I.L. Benito de Cardenas (2001). Influence of temperature on flavour compound production from citrate by Lactobacillus rhamnosus ATCC 7469. Microbiologyn Research 155: $257-$ 262.

Dimitrellou, D., Y. Kourkoutas., and A.A. Koutinas and M. Kanellaki (2009). Thermally-dried immobilized kefir on casein as starter culture in dried whey cheese production. Food Microbiology 26: 809-820.

Dimitrellou, D., P. Kandylis., A. Mallouchos., M. Komaitis., A.A. Koutinas and Y. Kourkoutas (2010). Effect of freezedried kefir culture on proteolysis in fetatype and whey-cheeses. Food Chemistry 119: 795-800.

Dubey, V.K., M. Pande., B.K. Singh and M.V. Jagannadham (2007). Papain-like proteases: Applications of their inhibitors. African Journal of Biotechnology 6 (9): 1077-1086. 
Dybing, S. T., J. A.Wiegand., S. A. Brudvig., E. A. Huang and R. C. Chandan (1988). Effect of processing variables on the formation of calcium lactate crystals on Cheddar cheese. Journal of Dairy Science 71:1701-1710.

Fox, P. F., J. Law., P. L. H. McSweeney and J. Wallace (1993). Biochemistry of cheese ripening. In P.F. Fox (Ed.), Cheese: Chemistry, Physics and Microbiology. Vol. 1 (2nd ed.) (pp. 389-438). London: Chapman and Hall.

Fox, P. F. and L. Stepaniak (1993). Enzymes in cheese technology. International Dairy Journal 3: 509-530.

Fox, P.F., T. K. Singh and P. L. H. McSweeney (1995). Biogenesis of flavour compounds in cheese. Adv. Exp. Med, 367: 59-98.

Fox, P. F. and J. M. Wallace (1997). Formation of flavour compounds in cheese. Advances in Applied Microbiology 45: 17-85.

Fox, P. F. and McSweeney, P. L. H. (1998). Dairy Chemistry and Biochemistry. Blackie Academic and Professional, London.

Fox, P. F., Guinee, T. P., Cogan, T. M. And Mc Sweeney, P. L. H. (2000). Fundamental of Cheese Science. Gaithesburg, Mayyland, An Aspen Publisher, Inc.

Hannon, J. A., K. N. Kilcawley., M. G. Wilkinson., C. M. Delahunty and T. P. Beresford (2007). Flavour precursor development in Cheddar cheese due to lactococcal starters and the presence and lysis of Lactobacillus helveticus. International Dairy Journal 17: 316-327.

Hill, A. R. (1995). Chemical species in cheese and their origin in milk components. In Chemistry of Structure Function Relationships in Cheese, Malin, E.L. and Tunick, M.H. Editors. Plenum Press, NY.

Hurley, M.J., L. B. Larsen., A. L. Kelly and R. L. H McSweeney (2000). The milk acid proteinase, cathepsin D: a review. International Dairy Journal 10: 673-681.
Katechaki., E., P. Panas., Y. Kourkoutas., D. Koliopoulos and A. A. Koutinas (2009). Thermally-dried free and immobilized kefir cells as starter culture in hard-type cheese production. Bioresource Technology 100: 3618-3624.

Magboul, A.A.A., L. B. Larsen., P. L. H. McSweeney and A. L. Kelly (2001). Cysteine protease activity in bovine milk. International Dairy Journal 11: 865-872.

Marilley, L. and M. G. Casey (2004). Flavors of cheese products: metabolic pathways, analytical tools and identification of producing strains. International Journal of Food Microbiology 90:139-159.

Nourani, A., E. Dako., A. Morsli., N. Belhamiche., S. Belbraouet., M. M. Bellal and A. Dadie (2009). Characterization of the purified coagulant extracts derived from Artichoke flowers (Cynara scolymus) and from the Fig tree latex (Ficus carica) in light of ntheir use in the manufacturer of traditional cheese in Algeria. Journal of Food Technology 7 (1): 20-29.

Olivecrona, T., Vilaro, S. and BengtssonOlivecrona, G. (1992). Indigenous enzymes in milk. II. Lipases in milk. In P. F. Fox (Ed.), Advanced dairy chemistry. 1. Proteins (pp. 292-310). London: Elsevier Applied Science.

Parente, E. and T. M. Cogan (2004). Starter cultures: general aspects. In Cheese: Chemistry, Physics and Microbiology, Vol 1: General Aspects, 3rd edn, pp 123-148. Fox P F, McSweeney P, L, H., Cogan, T. M. and Guinee, T. P. eds. London: Elsevier. 
Pastorino, J., C. L. Hansen and D. J. McMahon (2003). Effect of sodium citrate on structure-function relationships of cheddar cheese. Journal of Dairy Science 86: 3113-3121.

Rychlik, M. and J. O. Bosset (2001). Flavour and off-flavour compounds of Swiss Gruyere cheese. Identification of key odorants by quantitative instrumental and sensory studies. International Dairy Journal 11: 903-910.

Shetty, K., Paliyath, G., Pometto, A. and Levin, R. E.(2006). Food biotechnology. Ed $2^{\text {nd }}$, Taylor \& Francis Group: CRC Press.

Smit, G., J. E. T. van Hylckama Vlieg., B. A. Smit., E. H. E. Ayad and W. J. M. Engels (2002). Fermentative formation of flavor compounds by lactic acid bacteria. Australian Journal of Dairy Technology 7: 61-68.

Sousa, M. J., Ardo, Y. and P. L. H. McSweeney (2001). Advances in the study of proteolysis in cheese during ripening. International Dairy Journal 11: 327-345.
Tavaria, F. K., M. J. Sousa., A. Domingos., F. X. Malcata., A. Brodelius., A. Clemente and M. S. Pais (1997). Degradation of caseins from different milk types by extracts of Centaurea calcitrapa. Journal of Agricultural and Food Chemistry 45: 3760-3765.

Thierry, A. and Maillard, M.B. (2002). Production of cheese flavor compounds derived from amino acid catabolism by Propionibacterium freudenreichii. Lait 82: 17-32.

Walstra, P., J. T. M. Wouters and T. J. Geurts (2006). Dairy Science Technology. Ed $2^{\text {nd }}$, Taylor \& Francis Group, CRC Press. Yvon, M. and Rijnen, L (2001). Cheese flavor formation by amino acid catabolism.

International Dairy Journal 11: 185-201. 